\section{AL-AZHAR}

Assiut Dental Journal
The Official Publication of The

Faculty of Dental medicine.

Al-Azhar Assiut Uniuersity.

Egypt

\title{
Evaluation of Marginal Bone Level Changes Around Microthreaded Platform Switched Implant in The Aesthetic Zone
}

\author{
Hossam I. Abbas*, Mansour M. Hussien
}

Codex : 09/2020/04

Aadj@azhar.edu.eg

\section{KEYWORDS}

Marginal Bone Level,

Microthread,

Platform Switched Implant,

Aesthetic Zone, CBCT

1. Department of Oral and Maxillofacial surgery, Faculty of Dental Medicine (Boys),Cairo, Al-Azhar University, Egypt.

* Corresponding Author e-mail: hossamibraheem.9@azhar.edu.eg

\begin{abstract}
Aim: This study was designed to evaluate marginal bone level change around microthreaded platform switched implant in the aesthetic zone. Subjects and methods: Eighteen implant fixture were inserted in 16 patients with missing single tooth in upper anterior area and divided equally into two groups. The patients were selected from those attending outpatient clinic, Oral and Maxillofacial Surgery Department, at the Faculty of Dental Medicine, Boys, Cairo, Al-Azhar University. Clinical examination was made to all patients as: Inspection and palpation of muscles of mastication, tempromandibular joint, lymph nodes, occlusion, condition of the existing teeth and oral mucosa and available inter arch space. Preoperative periapical radiograph as well as, cone beam CT radiograghy for evaluation of the implant site. The patients were assessed clinically at the operative day and post-operatively for 6 months to evaluate implant stability with osstell, Probing depth (PD) and PES/WES score. Marginal bone loss was measured 6 months post-operatively using CBCT radiography. Results: The mean value of vertical bone loss after 6 months was $0.52 \pm 0.15$ in group I and $0.92 \pm 0.26$ in group II . This bone loss was increased in group II more than group I with statistical significant difference. The mean value of PES/WES total was $13.44 \pm 1.81$ in group II and 15.67 \pm 1.66 in Group I. This value was decreased in group II more than group I with statistical significant difference. Conclusion: The use of micro threads on the implant neck with platform switch was most effective design to maintain and preserve marginal bone level.
\end{abstract}

\section{INTRODUCTION}

A missing tooth in the anterior region usually requires prosthetic replacement for function and esthetic reasons. In the esthetic zone, crestal bone loss can lead to a collapse of soft tissues, bacterial leakage and adversely affect the esthetic of implant- prosthetic elements. The amount of crestal bone loss and location of biologic width may be associated with the thickness of soft tissue around the implant, this situation has important consequences for esthetic of interdental papillae which can suffer mesial and distal bone loss ${ }^{(1,2)}$. 
Recently, the crestal bone resorption has been reduced by adding a rough external surface on the transosteal portion of an implant fixture. The mechanical benefit is an increase in implant-bone contact available for stress translation by roughened surface results from the addition of microthreads to the neck $\mathrm{k}^{(3,4)}$.

a) B.D.S 2009 G, Faculty of Oral and Dental medicine Cairo University Dentist, Ministry of Health.

b) Professor, Oral and Maxillofacial Surgery, Faculty of Dental Medicine Boys, Cairo Al-Azhar University

Accordingly, placing of micro-threads on the implant neck greatly increases the ability of an implant to resist axial loads and the mechanical stimulus provided by the micro-threads helps to preserve peri-implant marginal bone ${ }^{(5)}$. Microthreading of implant increases the resistance of marginal bone loss by improving the interlocking force between the implant surface and the crestal bone. So that, the mechanical properties of bone around microthreads system found to be more resistant to compressive forces than tensile and shear forces. Therefore, bone loss decreased at the first thread of the implant fixture ${ }^{(6-8)}$.

A new implant to abutment connection referred to as "platform switching" has been proposed ${ }^{(9)}$. The platform switching concept is based on the use of an abutment smaller than the implant neck ${ }^{(10)}$, this type of connection moves the perimeter of implant abutment junction (IAJ) to the center of implant axis $^{(11,12)}$. It is likely that moving the IAJ inward brings out bacteria more internally and therefore away from the bone crest, this would explain the limitation in bone resorption ${ }^{(13,14)}$. Recent studies suggested the formation of a more consistent connective sleeve when the abutment's base is smaller than the implant platform, with advantages in the ability to form a mucosal seal ${ }^{(15)}$. While other stud- ies ${ }^{(16,17)}$, evaluated marginal bone level changes around micro-threaded and platform switched implant and concluded that it is associated with successful survival rates and reduces marginal bone loss but further long-term clinical and advancement imaging study are required ${ }^{(18,19)}$.

\section{AIM OF THE STUDY}

The aim of this study was to evaluate marginal bone level change around microthreaded platform switched implant in the aesthetic zone.

\section{PATIENT AND METHODS}

This Randomized Controlled Clinical Trial study was conducted on sixteen adult patients of both genders. Patients had a maxillary single missing tooth, two of the patients had bilateral missing lateral incisors. All missing areas had adequate width and height of the alveolar bone to receive an implant by two stage delayed loading non submerged healing protocol. An informed consent was obtained from all patients. The patients were selected from the Out Patient Clinic of the Oral \& Maxillofacial Surgery Department, Faculty of Dentistry, Al-Azhar University.

\section{Patients were divided into two groups:}

Group (I): Eight patients received 9 microthreaded platform switched implants to replace a missing single tooth in the upper anterior area with different diameter and length according to the case by 2 -stage non submerged dental implant with delayed loading technique.

Group (II): Eight patients received 9 non micro-threaded platform switched implant to replace a missing single tooth in the upper anterior area with different diameter and length according to the case by 2 -stage non submerged dental implant with delayed loading technique. 


\section{The Implant system:-}

Implant (Two-stage screw dentuim Implant System (NR and superline systems)

\section{A - Preoperative phase}

All patients underwent pre-operative clinical examination: Patients' data were collected; name, gender and age, medical and dental histories were taken and the oral mucosa of the edentulous area was examined by inspection and palpation. all patients underwent standardized periapical radiography to detect any periapical pathology and a pre-operative CBCT radiograph examination to determine optimal implant position and select the proper size of the implants to be installed.

\section{B -Operative phase}

Patients were instructed to rinse with Hexitol* mouth wash before surgery. Surgical area was swapped with Betadine mouth gargle, then local anesthesia infiltration using Mepevacaine $\mathrm{Hcl} 2 \%$ with vasoconstrictor as levonordefrine 1:20,000.

A mid-crestal incision was performed and reflection of the mucoperiostal flap was done. Then optimal implant position was determined, taking both the aesthetic and biomechanical aspect into consideration. The implant was placed at cestal bone level according to groups.

In group (I), after determining the optimal position, diameter and length of the implant according to the case, drilling was done in sequentional manner. Microthreaded plateform switched implant was removed out of its vial with implant rotary driver and inserted into osteotomy site using implant motor at crestal bone level with torque of 35 N. Smart peg was applied to implant to determine and read the primary stability with Osstell machine. Healing abutment was placed and connected to the fixture. Flap was replaced to its original position and sutured using an absorbable polyglactin sutures (000 vicryl) to allow for non submerged healing.
In group (II), after determining the optimal position, diameter and length of the implant according to the case, drilling was done in sequentional manner. Then implant with non microthreaded platform switched (superline dentum implant system) was removed out of its vial and Ratchet was used to insert it into osteotomy site at crestal bone level as same as a forementioned in first group .

\section{Prosthetic phase:-}

Secondary stability was measured using osstell After 4 months post-operatively after removing of the healing abutment and smart pig application into the implant fixure. The smart pig was removed and impression was taken (two stage closed tray impression technique). Zirconia crown was fabricated and cemented in the implant abutment.

\section{Follow up phase}

\section{Clinical evaluation}

The patients were assessed clinically at the operative day and post-operatively for 6 months to evaluate implant stability with osstell, Probing depth (PD) and PES/WES score.

\section{1- Osstell:}

Implant stability was assessed intra-operatively with Osstell after implant placement to determine primary stability and after 4 months postoperatively to assess secondary stability. Transducer comprises two elements one is vibrated by signal and the other is a receptor for the signal. Osstell has a computerized analysis and a measurement unit (Implant Stability Quotient) ISQ is from 0 to 100 , the successful implant should be more than 50 ISQ. Failure implant if reading less than 47.

2- Probing $\operatorname{depth}(\boldsymbol{P D})$ is the distance between the periimplant gingival margin and the bottom pocket. Measurement was done at 4 and 6 months following implant placement to determine the status 
of the peri-implant tissues. Each record was done by taking six readings from the full circumference of; mesiofacial, midfacial, distofacial, mesiolingual, midlingual and distolingual. The mean of these six readings was then calculated and recorded. These measurements were done using a graduated probe.

\section{3-PES/WES index}

PES/WES evaluation were done at 6 months after implant placement.The PES designates five scores; mesial papilla, distal papilla, curvature of the facial mucosa, level of the facial mucosa, and root convexity/ soft tissue color and texture at the facial aspect of the implant site. A score of 2, 1, or 0 is assigned to all five PES parameters which results in a maximum possible score of 10 .

WES was based on the five following parameters: general tooth form, outline and volume of the clinical crown, color which includes the assessment of the dimension's hue and value, surface texture and translucency and characterization. A formentioned parameters were taken comparing to contralateral tooth. A score of 2,1 , or 0 is assigned to all five parameters results in a maximum possible score of 10. PES/WES is a combination of PES and WES with the highest possible score of 20.

\section{B) Radiographic parameters:}

CBCT was done immediately and at 6 months Post-operatively to assess and evaluate bone density and vertical bone loss as the following;

\section{1-Bone density}

Bone density was assessed with grey scale value ${ }^{(190,191)}$. all the patients were examined by radiologist with a same CBCT machine and software. Measurements were done in a grey scale by the same radiologist in a 7 points , 3 mesial, 3 distal and 1 apical . The mean value of these points was recorded for each implant.

\section{2-Assessment of vertical bone loss}

This evaluation was applied to assess vertical bone loss from crestal bone height to the apex of the implant. This was done by drawing horizontal line represents the apex of the implant and 2 vertical, mesial and distal lines extended from the horizontal line to crestal bone height. The mean value of mesial and distal measurements was recorded. Fig (1)

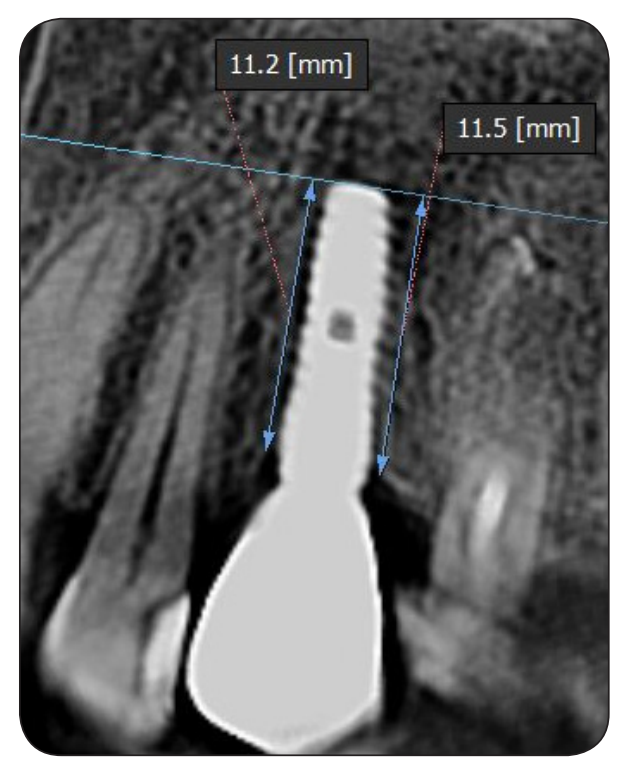

Fig. (1) A photograph showing CBCT after 6 months to measure vertical bone loss.

C-Patient satisfaction was recorded in (VAS) from 0 to 10 . The value of 0 means no satisfaction while increasing in number means more satisfaction till optimum at No of 10 .

\section{Statistical analysis:}

The data was collected, coded, tabulated and analyzed statistically, by using Statistical Package for Social Science (SPSS) software program (version 23.0) to obtain. Descriptive statistics were calculated in the form of Mean \pm Standard deviation (SD) which used for parametric values. Median \& interquartile range(IQR) and Frequency(numberpercent) used for non parametric values. A $\mathrm{P}$ value $<0.05$ was considered statistically significant. 


\section{RESULTS}

Eighteen implant fixures were inserted in sixteen patients devided equally into two groups , two patients of the sixteen had bilateral missing lateral tooth. Each group received 9 implants in the esthetic zone. Each patient in group I received microthreaded platform switched implant to restore a missing single tooth in the esthetic area, while in group II each patient received non microthreaded platform implant to restore a missing single tooth in the esthetic area. All patients underwent surgery in local anesthesia and no complications had been recorded during the operation.

\section{Clinical results}

1- Implant diameter \&Implant length: The mean value of Implant diameter in group I was 3.38 0.21 and $3.80 \pm 0.15$ in group II with significant increase in group II $(\mathrm{p}=<0.001)$. Also implant length of group I was12.33 \pm 1.00 and $11.56 \pm 1.33$ in group II without statistical significant difference $(\mathrm{p}=0.18)$.

\section{2-Implant stability quotient (ISQ)}

Immediately after implant insertion, the mean value of implant stability quotient(ISQ) was $60.56 \pm 5.25$ in the group I and $60.33 \pm 6.78$ in the group II with non-significant differences between them $(p=0.93)$. After 4 months post-operatively in group I the mean value of (ISQ) was $76.00 \pm 3.39$ and $73.56 \pm 4.59$ in group II with non-significant differences between them $(p=0.2)$. There was an increase in implant stability quotient (ISQ) after 4 months in both groups . more increase was observed in group I without statistical significant difference between them $(p=0.34)$.

\section{3-Probing depth}

At 4 and 6 months post-operatively, The mean value of probing depth in the Group II was $2.08 \pm 0.52$ and $1.83 \pm 0.50$, while in group I the mean value was $1.83 \pm 0.36$ and $1.64 \pm 0.33$ respectively without statistical significant difference. The mean value of change from 6 months to 4 months was $-0.25 \pm 0.08 ;-12.23 \pm 4.44$ in group II and $-0.19 \pm 0.05 ;-10.33 \pm 2.35$ in group I respectively without statistical significant difference.

\section{4-PES, WES and PES/WES total}

The mean value of PES in group II was $6.44 \pm 0.88$ and in Group I was $7.78 \pm 0.97$. This value was decreased in group II more than group I with a statistical significant difference $(\mathrm{p}=0.008)$. The mean value of WES was $7.00 \pm 1.00$ in group II and $7.89 \pm 0.93$ in group I with no statistical significant difference between them $(\mathrm{p}=0.068)$. The mean value of PES/WES total was $13.44 \pm 1.81$ in group II and $15.67 \pm 1.66$ in Group I. This value was decreased in group II more than group I with statistical significant difference $(\mathrm{p}=0.015)$

\section{5-Patient satisfaction by VAS.}

After 4 months post-operatively and crown cementation, the mean value of patient satisfaction showed no significant difference between the two groups.

\section{Cone beam analysis}

\section{1-Vertical bone loss after 6 months}

The mean value of vertical bone loss after 6 months was $0.52 \pm 0.15$ in group I and $0.92 \pm 0.26$ in group II . This bone loss was increased in group II more than group I with statistical significant difference $(\mathrm{p}=0.001)$ ( Tab.1 and Fig. 2).

Tab. (1): Comparison of Vertical bone loss after 6 months between Group I \& Group II.

\begin{tabular}{|l|c|c|c|c|c|c|}
\hline \multirow{2}{*}{} & \multicolumn{2}{|c|}{$\begin{array}{c}\text { Group I } \\
(\mathrm{n}=9)\end{array}$} & \multicolumn{2}{|c|}{$\begin{array}{c}\text { Group II } \\
(\mathrm{n}=9)\end{array}$} & \multirow{2}{*}{ Test used } & \multirow{2}{*}{ P } \\
\cline { 2 - 6 } & Mean & \pm SD & Mean & \pm SD & & \\
\hline Vertical bone resorption after 6 months & 0.52 & 0.15 & 0.92 & 0.26 & $\mathrm{t}=-3.930$ & $0.001 *$ \\
\hline
\end{tabular}

Data expressed as mean \pm SD $\quad$ SD: standard deviation $\quad$ P:Probability $\quad *$ :significance $<0.05$

Test used: Student's t-test(unpaired) 


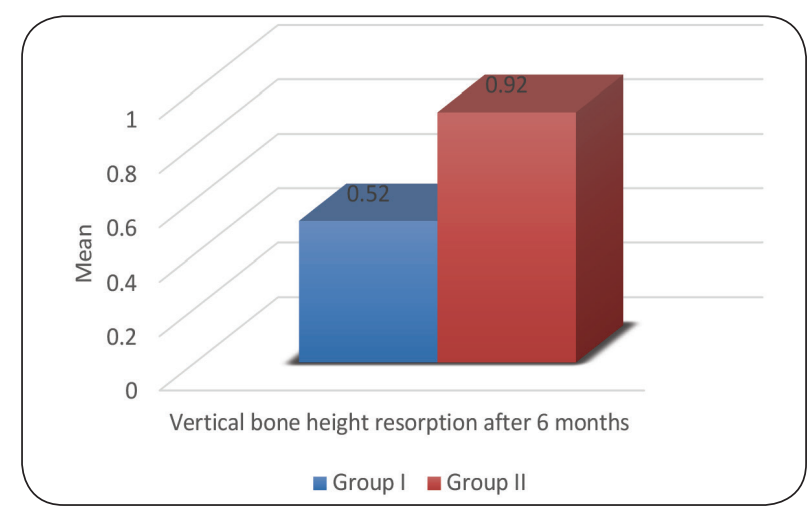

Fig. (1) Bar chart showing comparison in vertical bone loss after 6 months between Group I and Group II.

\section{2-Bone density}

Bone density at 6 months postoperatively showed no statistical significant difference between the two groups.

\section{DISCUSSION}

Surgical placement of dental implants in the aesthetic area requires careful treatment planning, particularly in terms of fixture selection and implant positioning. Placing micro-threads on the implant neck greatly increases the ability of an implant to resist axial loads. Also the mechanical stimulus provided by the micro-threads helps to preserve periimplant marginal bone ${ }^{(20)}$. There were many reports discussed the influence of surface roughness on the bone-implant interface with respect to marginal bone loss. In 1990 Wilke and associate ${ }^{(21)}$ reported an increased resistance to interfacial shear strength between implant and bone when the surface of the implant was roughened in some way. Some studies evaluated marginal bone loss with usage of microthreaded implant neck and found that it helped in marginal bone preservation through decreasing the peak interfacial shear stress on the cortical bone ${ }^{(22)}$. The concept of platform switch (PLS) has been considered in some articles, including case reports ${ }^{(9)}$. These case reports and some clinical findings suggested that PLS implants help in preservation of the peri-implant crestal bone and superior soft tissue conditions. This type of connection shifts the perimeter of the implant-abutment junction (IAJ) inward toward the central axis of the implant ${ }^{(23)}$. Lazzara et al. ${ }^{(9)}$ have hypothesized that shifting the IAJ inward also shifts the inflammatory cell infiltrate inward and away from the crestal bone so it helps in decreasing marginal bone loss.

The present study was planned to examine the effect of micro-threaded implant neck with platform switch on the marginal bone level. In particular, we compared the effect of micro-threaded platform switched implant with non microthreaded platform switched implant on crestal bone and related soft tissue in the aesthetic zone. Eighteen implant fixures were inserted in sixteen patients devided equally into two groups, two patients of the sixteen had bilateral missing lateral tooth. Each group received nine implants in the esthetic zone. Each patient in group I received microthreaded platform switched implant to restore a missing single tooth in the esthetic area, while in group II each patient received non microthreaded platform switched implant to restore a missing single tooth in the esthetic area. In each group different implant lengths and diameters were used according to case.

All implants in the present study were successful with primary and secondary stability assessed with resonance frequency analysis. The primary implant stability was $60.33 \pm 6.78$ in the group I and $73.56 \pm 4.59$ in the group II. ISQ in group I and group II was increased to $60.56 \pm 5.25$ and $76.00 \pm 3.39$ respectively 4 months post-operatively.

Evaluation of probing depth in the two groups was done 4 months and 6 months post-operatively. It is found that there was decrease in probing depth in the two groups at 6 months post-operatively compared to that at 4 months. The percent of change from 4 months to 6 months in in group I was $10.33 \pm 2.35 \%$ and $12.23 \pm 4.44 \%$ in group II without significant difference. In this study PES/WES index was used to evaluate esthetic in the anterior region. PES was de- 
creased in group II more than group I with a statistical significant difference. There was no significant difference in WES between the two groups. PES/ WES total was significantly increased in group I more than group II.

Radiographic evaluation, CBCT was used to determine the bone density and vertical bone loss. Bone density was measured using gray scale value. It was $824.44 \pm 24.55$ in group I and $799.44 \pm 16.85$ in group II. There was no significant difference between them. CBCT also was used to evaluate vertical bone loss. In this study the effect of micro-threaded platform switched implant was compared with non microthreaded platform switched implant on the marginal bone. Vertical bone loss with microthreaded platform switched implant was less than that of non microthreaded platform switched implant. So microthreaded implant neck with platform switched has a significant effect on preservation of marginal bone and corresponding soft tissue in the esthetic area.

\section{CONCLUSIONS}

According to the result of this study it was concluded that The use of micro threads on the implant neck with platform switch was most effective design to Maintain and preserve marginal bone level.

\section{REFERENCES}

1. Tae J, Joong K, Carl E, Hom-Lay W. The cause of implant bone loss: myth or science? j Periodontol 2002; 73: 322-33.

2. Hermann F, Lerner H, Palti A. Factor influencing the preservation the peri implant marginal bone. Impl Dent 2007; 16: 165-75.

3. Kim J, Lee D, Kim C, Park K, Moon I. Effect of conical configuration of fixture on the maintenance of marginal bone level: preliminary results at 1 year of function. Clin Oral Impl Res 2010 ; 21: 439-44.

4. Abrahamsson I, Berglundh T. Tissue characteristics at microthreaded implants: An experimental study in dogs. Clin Impl Dent Relat Res 2006; 8: 107-13.
5. Song D, Lee D, Kim C, Park K, Moon S. Comparative analysis of peri-implant marginal bone loss based on microthread location: a 1-year prospective study after loading. J Periodontol 2009; 80: 1937-44.

6. Schrotenboer J, Tsao Y, Kinariwala V, Wang H. Effect of microthreads and platform switching on crestal bone stress levels: a finite element analysis. J Periodontol 2008; 79 : 2166-72.

7. Yun H, Park J Jung U, Kim C, Choi S, Cho K. A shortterm clinical study of marginal bone level change around microthreaded and platform-switched implants. J Perio Impl Sci 2011; 41: 211-17.

8. Abuhussein H, Pagni G, Rebaudi A ,Wang H. The effect of thread pattern upon implant osseointegration. Clin Oral Imp Res 2010; 21: 129-36.

9. Lazzara R, Porter S. Platform switching: a new concept in implant dentistry for controlling postrestorative crestal bone levels. Int J Periodontol Res Dent 2006; 26: 9-17.

10. Calvo-Guirado JL, Ortiz-Ruiz AJ, Lopez-Mari L, DelgadoRuiz R, Mate-Sanchez J, Bravo Gonzalez La. Immediate maxillary restoration of single-tooth implants using platform switching for crestal bone preservation: a 12-month study. Int J Oral Maxillofac Impl 2009; 24: 275-81.

11. Maeda Y, Miura J, Taki I, Sugo M. Biomechanical analysis on platform switching: Is there any biomechanical rationale? Clin Oral Impl Res 2007; 18: 581-84.

12. Schrotenboer J, Tsao YP, Kinariwala V, Wang HL. Effect of microthreads and platform switching on crestal bone stress levels: A finite elements analysis. J Periodontol 2008; 79: 2166-72.

13. Ericsson I, Randow K, Nilner K, PetersonA. Early functional loading of Brånemark dental implants: 5-year clinical follow up study. Clin Impl Dent Relat Res 2000; 2: 70-7.

14. Quirynen M, Van Steenberghe D. Bacterial colonization of the internal part of two-stage implants. An in vivo study. Clin Oral Impl Res 1993; 4: 158-61.

15. Canullo L, Fedele GR, Iannello G, Jepsen S. Platform switching and marginal bone level alterations: the results of a randomized-controlled trial. Clin Oral Impl Res 2010; 21: $115-21$

16. Langn, Berglundh T. Periimplant diseases: where are we now? Consensus of the Seventh European Workshop on Periodontology. J Clin Periodontol 2011; 38: 178- 81.

17. Song D, Lee D, Kim C, Park K, Moon S. Comparative analysis of peri-implant marginal bone loss based on microthread location: a 1-year prospective study after loading. J Periodontol 2009; 80: 1937-44. 
18. Ericsson I, Johansson C, Bystedt H, Norton $M$. Ahistomorphometric evaluation of bone-to-implant contact on machine-prepared and roughened titanium dental implants. Clin Oral Impl Res 1994; 5: 202- 6.

19. Baumgarten H, Cocchettor, Testori T, Meltzer A, Porter S. A new implant design for crestal bone preservation: Initial observations and case report. Pract Proceed Aesth Dent 2005; 17: 735- 40.

20. Hansson, S. The implant neck: smooth or provided with retention elements. A biomechanical approach. Clinl Oral
Impl Res 1999: 10: 394-405.

21. Chang M,Odman PA, Wennstrom JL,Andersson B. Esthetic outcome of implant-supported single-tooth replacements assessed by the patient and by prosthodontists. Int $\mathrm{J}$ Prosthodont. 1999; 12: 335-41.

22. Wilke HJ, Cleas L, Steinemann S. The influence of Various titanium surgeries on the interface shear strength between implants and bone. Advances in Biomat 1990; 9: 309-14.

23. Gardner DM. Platform switching as a means to achieving implant esthetics. N Y State Dent J 2005; 71: 34-7. 


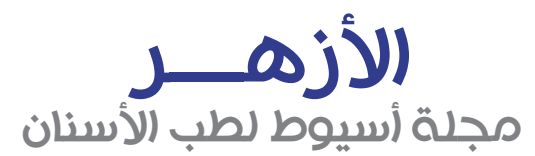

النشر الرسمي لكلية طب الأسنان جامعة الأزهر أسيوط الكاية

\title{
تقييم حافة العظم حول الغرسات واسعة المنصة ذات الحلزونات

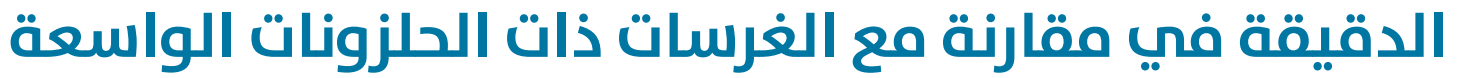 المنتنظمة في المنطقة الجما لية للفم
}

\author{
حسام ابراهيه عباس** ، منصور محمد حسين \\ 1. قسـم جراحة الفهم والوجه والفكين، كلية طب الاسنان (بنين ( ,القاهرة، جامعة الأزهر، جمهورية مصر العربية

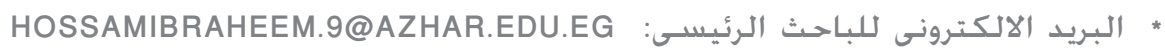

(الملخص:

الهـدف : كان الهدف من الدراسـة الحالية هو تقييهم حافة العظم حـول الغرسات واسعة المنصة ذات الحلـزونات الدقيقة في مقارنة مع الغرسات

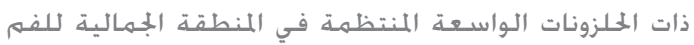

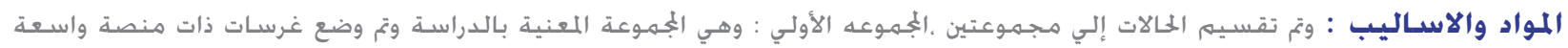

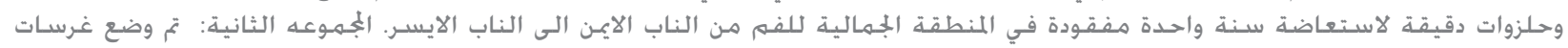

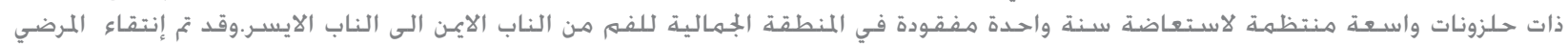

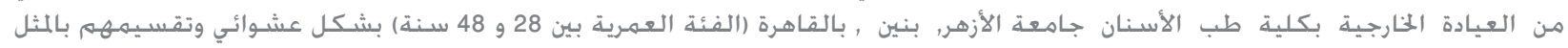

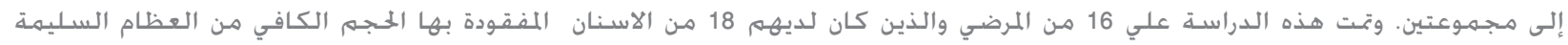

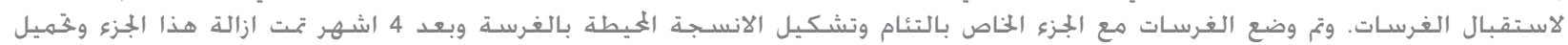

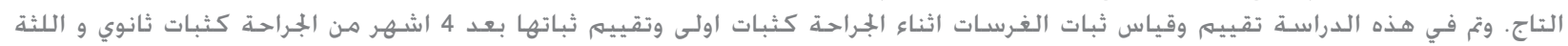

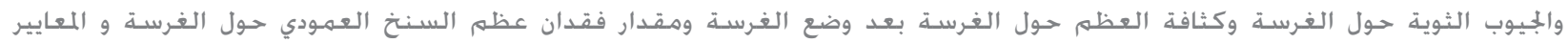

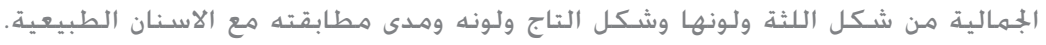

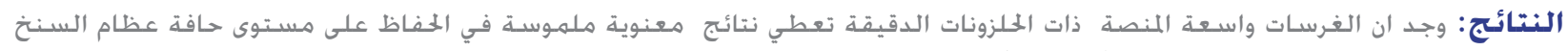

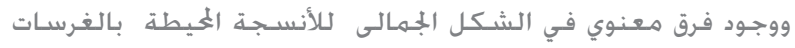

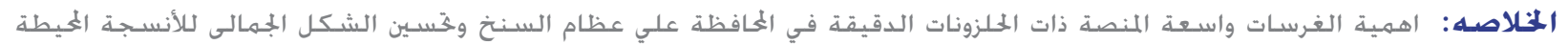
بالغرسات في المنطقة الجمالية للفمر الإهات

الكعلمات المفتاحيه: حافة العظم حول الغرسات ، الحلزونات الدقيقة ، الغرسات واسعة المنصة ، المنطقة الجمالية للفم ، الاشعه المقطعيه الحلزونيه 